folk/ed. Derg, 2020; 26(1): 23-39

DOI: $10.22559 /$ folklor.1157

\title{
Kültür Turizmi Bağlamında Mekânın Ötekileştirilmesi ve Yeniden Üretimi Örneği: Beypazarı Evleri*
}

\author{
Reproduction and Marginalization of Space within the \\ context of Culture Tourism: \\ The Example of Beypazari Houses
}

Sema Demir**

$\ddot{O} z$

Modernleşme, Osmanlıdan günümüze geleneğin pek çok alanda ötekileştirilmesiyle mümkün olmuştur. Modernleşme sürecini yöneten dolayısıyla geleneğin hangi veçhesiyle ötekileştirileceğine hükmeden siyasî iktidar yeni yaşam biçimlerinin benimsetilmesi için çeşitli devlet politikaları geliştirmiştir. Bu süreçte yeni tarz hayatı mümkün kılan ve geleneğin pek çok unsuruyla değişip dönüşmesine imkan sağlayacak kültür unsuru "ev, konut" olarak seçilmiştir. Tanzimat'la başlayan bu süreç kendi içinde yerini üç oda bir salon mitine ve son zamanlarda residence evlere bırakmış görünmektedir. Geleneksel yapılar ise çağrıştırdığı bütün geleneksel unsurlarıyla ötekileştirilmiş olsa da kültür turizminin etkisiyle günümüzde yeniden üretime tâbî tutuldukları görülmektedir. Modernizmle toprağın altına gömülen geleneksel mekânların, postmodernizmle yeniden dirildikleri ileri sürülebilir. Çalı̧̧-

Geliş tarihi (Received): 07 Mayıs 2019 - Kabul tarihi (Accepted):14 Ekim 2019

Bu makale, 27 Haziran-1 Temmuz 2006 tarihinde VII. Milletlerarası Türk Halk Kültürü Kongresinde sunulan bildirinin yeniden düzenlenmesi ile oluşturulmuştur.

** Dr. Öğr. üyesi. Ankara Sosyal Bilimler Üniversitesi Türk Dili ve Edebiyatı Bölümü. semadmr@gmail.com. ORCID ID: 0000-0002-2730-7745. 
mada Beypazarı evlerinin postmodern süreçte, kültür turizmi bağlamında mekân olarak nasıl yeniden üretildiği örneklerle ortaya konacaktır. Çalışma bu yönüyle sahadan örneklerin sunulacağı bir alan araştırmasıdır. Bu alan araştırmasından elde edilen veriler özellikle Jean Baudrillard'ın simulark ve simülasyon, İrvin Cemil Schick' in yerin mekân olma süreci ve yeniden üretimi kuramlarıyla işlenmiştir.

Anahtar sözcükler: Beypazarl, Beypazarı evleri, kültür turizmi, ötekileştirme, yeniden üretim

\begin{abstract}
Modernization could become possible by marginalization of tradition on several domains of life. The political power who directed the modernization process, that is, who shall decide which portions of the tradition shall be marginalized has developed new state policies in order to enable the adaption of the new life styles by the people. In this paper, the cultural factor which has made possible the new life style which is potential to convert what is traditional in several aspects of culture, is chosen as "house, residential units". This process which was started by the Tanzimat reform era of Ottoman Period in $19^{\text {th }}$ century has been transformed into the myth of three-rooms-one hall and recently, into the residence houses fashion. The traditional houses, on the other hand, although have appeared to be marginalized together with all of its traditional aspects which they are associated with they have started to be subject to reproduction through the impetus of cultural tourism fashion. The conservative spaces which we have buried in the ground through modernism can be said to have been revived through postmodernism. the process of how the Beypazari houses are reproduced as spaces within the context of culture tourism fashion shall be illustrated in this study with examples. Therefore, as examples from the field shall be presented in this paper, it is qualified as a field study. The data that is obtained from this field study are analyzed according to the models of Jean Baudrillard's simulacrum and simulation and Irvin Cemil Schick's concept regarding the transition process of the areas into the spaces.
\end{abstract}

Keywords: Beypazari, Beypazari houses, culture tourism, marginalization, reproduction

\title{
Giriş
}

Geleneği ötekileştirmek, Osmanlıda özellikle 18. yüzyılın başından bu yana iktidarın modernleşme sürecini hızlandırmak için kullandığ 1 politikalardan biri olmuştur. ${ }^{1}$ Modern olana ait değerlerin ve bu değerler üzerine kurulu yaşam biçiminin halka benimsetilmesine yönelik girişimler bir devlet politikası olarak yürütülmüştür. Bu yaşam tarzı, birçok yönüyle farklı dönemlerde model alınmıştır. Söz konusu "modern yaşama eğilimi” en belirgin biçimde kendini mekân örneğinde göstermiştir. Tanzimat döneminden itibaren geleneksel mimarî hızla yerini "modern" apartmanlara bırakmıştır. Bu dönem edebiyatında da sıkça işlenen, yalıları, konakları terk ederek apartmanlaşmaya yöneliş olgusu ivmesinden fazlaca kaybetmeksizin günümüze değin gelmiştir. Geleneksel Türk konutu "Batılılaşma" yahut "Modernleşme" olarak adlandırılan dönemde iyiden iyiye itibardan düştüğünde üç oda bir salon apartman dairelerinin salgın bir has- 
talık gibi ülke coğrafyasına yayıldığı bilinmektedir. Modernizmin bire bir yansıması sayılabilecek bu durum aslında ilginç bir tersine çevirmeyle XX. yüzyıl sonlarında dönüşüme uğramıştır.

Jean Baudrillard'ın gerçek (hakikat) tanımlamasında, günümüzde gerçeğin önce öldürülmesi sonra da onu diriltmek için çaba harcanması gerektiği ve gerçekliğin ancak bu şeklide elde edildiği savını (2005: 26) üzerinde durduğumuz konu için şu şekilde değiştirmek mümkündür: Yeniden üretimin gerçekleşmesi için üretime tâbi tutulacak olanın öldürülmesi gereklidir. Modernizmle toprağın altına gömmüş olduğumuz geleneksel mekânlar, postmodernizmle yeniden dirildiler. Ancak bir ölünün tekrar ete kemiğe bürünmesini sadece kutsal metinlerde anlamlı bulan zihnimiz aslında mekânların dirilişinin de gerçek olmadığını fark eder. Ne var ki bu farkındalık, süreci etkilemez. Öldürülenin ya da ölenin hayat bulma süreci, "yeniden üretim”, "yeni işlev kazanma", "yeniden yapılanma" gibi değişik biçimlerde ifade edilmektedir. Yeniden üretilenler belli endüstrileri, çalışma alanlarını, yapılanmaları, farklı toplumsal örgütlenme biçimlerini doğurmuştur. Kültür turizmi de, "yeniden üretim" olgusuyla ortaya çıkan bir üretim-tüketim biçimidir.

Çalışmada Türkiye'de kültür turizmi konusunda öncü kültür destinasyonları içinde yer alan Beypazarı evlerinin ve kamusal mekânlarının modernizm sürecinde önce ötekileştirilmesi ve postmodernizmle yeniden üretilmesi üzerinde durulacaktır. Bu araştırma, Beypazarı ilçe merkezinde gerçekleştirilmiştir. Beypazarı günümüzde içinde yaşama oranının neredeyse \% 90'a ulaştığı 3500 geleneksel eve sahiptir. İlçenin merkezinde bulunan bu evlerden 495 tanesinin dış cephesinin basit cephe onarımı 2000-2001 yılları arasında "Beypazarı Yeniden Projesi” ile Beypazarı Belediyesi tarafından yapılmıştır. 2011-2012 yıllarında Beypazarı tarihî çarşısında Develik, Kuyumcular, Dikiciler, Bostancılar, Demirciler Sokaklarında restorasyon çalışmaları yürütülmüşsür. 2015'te ise Beypazarı turizmin kalbi olarak nitelenecek Alaaddin Sokak’taki geleneksel evlerin dış cephe basit onarımları gerçekleşmiştir.

Sözü edilen geleneksel çarşıların, sokakların, evlerin yanı sıra tarihî doku ya da yerleşim içinde yer alan modern mekânlara da 2000-2001 döneminde Beypazarı Belediyesi tarafından geleneksel görünüm verilmiştir. Beypazarı, sözü edilen geleneksel ve modern mekânların geçirdiği fiziksel ve işlevsel değişimlerin modernizm ve postmodernizm bağlamında değerlendirilmeye uygun olarak sunduğu veriler nedeniyle bu çalışmanın nesnesi olarak seçilmiştir. Bu analiz, Beypazarı'nın turizm destinasyonu hâline gelmeden evvel 1992 yılından turizm çalışmalarının ivme kazandığı 1999’a ve güncel döneme kadar bölgede sürdürülen gözlem, derleme, sözlü tarih çalışmalarına ve bunlardan elde edilen değerlendirmelere dayanmaktadır. ${ }^{2}$ Yazıda geleneksel Beypazarı evlerinin, modernizm ve postmodernizm bağlamında önce ötekileştirilmesi sonra yeniden üretilmesi ile tarihî dokuda yer alan ve önce benimsenen sonra ötekileştirilen modern yapıların gizlenmesi için yapılan uygulamalar analiz edilecektir. Bu değerlendirmede Irwin Cemil Schick'in "mekân teknolojileri” terimi merkezde yer alacaktır. Bunun yanı sıra Baudrillard'ın simülasyan kuramından da faydalanılacak ve mekân teknolojilerinin modernizm ve postmodernizm açısından görünümü ve turizm amaçlı kullanımı irdelenecektir. Mekânın ötekileştirilmesi ve yeniden üretimi için gerekli olan koşullar, durumlar Beypazarı özelinde kullanım biçimleri örneklendirilerek açıklanacaktır. Yeniden keşfedilenin kültür turizmine temel olma süreci ana temine geçmeden önce Beypazarı'nda mekânın bir imge olarak Baudrillard'ın deyimi ile derin gerçekliği yansıttığı dönemden derin gerçekliğin yokluğunu gizlediği döneme (1996: 20) değin geçirdiği süreci betimlemekle işe başlamak konuyu daha anlaş1lır kılacaktır. 


\section{Mekânın derin gerçekliği ve bu gerçekliğin yitirilişi: Beypazarı evleri}

Michel Foucault'nun toplumsal gerçeklikler ve kurumlara dair bilginin inşasında yararlanılan söylemsel araçları anlatmak için kullandığı "teknoloji” terimini Schick, Batının Cinsel Kıyısı adlı çalışmasında, yerin mekân olma, yâni toplumsal olarak üretilme ve yeniden üretilmesinde kullanılan söylemsel araçları ve stratejileri betimlemek için "mekân teknolojileri" biçimde değiştirmiştir (2000: 8). Kısaca mekânın üretilme araçları olarak tanımlanabilecek mekân teknolojileri yeri mekânlaştıran birtakım eylemler, söylemlerdir. Schick, yerin toplumsal üretimi ve yeniden üretimi sırasında pek çok mekân teknolojisi kullanıldığını gösterir. Kullanılan bu mekân teknolojilerinden en önemlisi "ötekileştirme”dir. Nitekim, kimliğin inşası "başkalığın” inşasıından ayrılmaz. Kimliğin inşası ancak başkalıkla karşı karşıya konduğu zaman bir anlam ifade eder. Başkalarına kim olduğumuza dair öyküler anlattı̆̆ımızda aslında kim olmadığımızı da söylemiş oluruz. Kimlik ve başkalık mekân algısıyla yani "bura" ve "ora" ile yakından ilgilidir. Schick mekân teknolojilerini açıklamaya "anlatı"larla devam eder. Yerin mekân olma sürecinde kendimize ve başkalarına anlattığımız öyküler yeri insanîleştirir. Başka kültürler ve coğrafyalarla belli zamanlarda yaşanan kesişmeler de mekân teknolojileri içinde yer alır. Haritalama, adlandırma, ötekileştirme, bilmezlik, cinsiyetlendirme ve cinselleştirme ise Schick'in ele aldığı diğer mekân teknolojileridir (2000: 9-41). Geleneksel Beypazarı evlerinin yeniden üretim sürecinde Schick'in sözünü ettiği "mekân teknolojisi”nin yanı sıra birçok mekânsal teknoloji biçimi de bu süreçte kullanılmıştır.

Beypazarı'nda Anadolu'nun pek çok yerleşim biriminde olduğu gibi geleneksel ve modern yaşam alanları şehirlerarası kara yoluyla birbirinden ayrılır. Modernizmin karakteri itibarıyla yerel olandan kurtulma, kültürel izlerden soyutlanma çabası, Beypazarı bağlamında İstanbul-Ankara kara yolu çizgisinde kendini gösterir (Demir, 2003). (Fotoğraf 1)

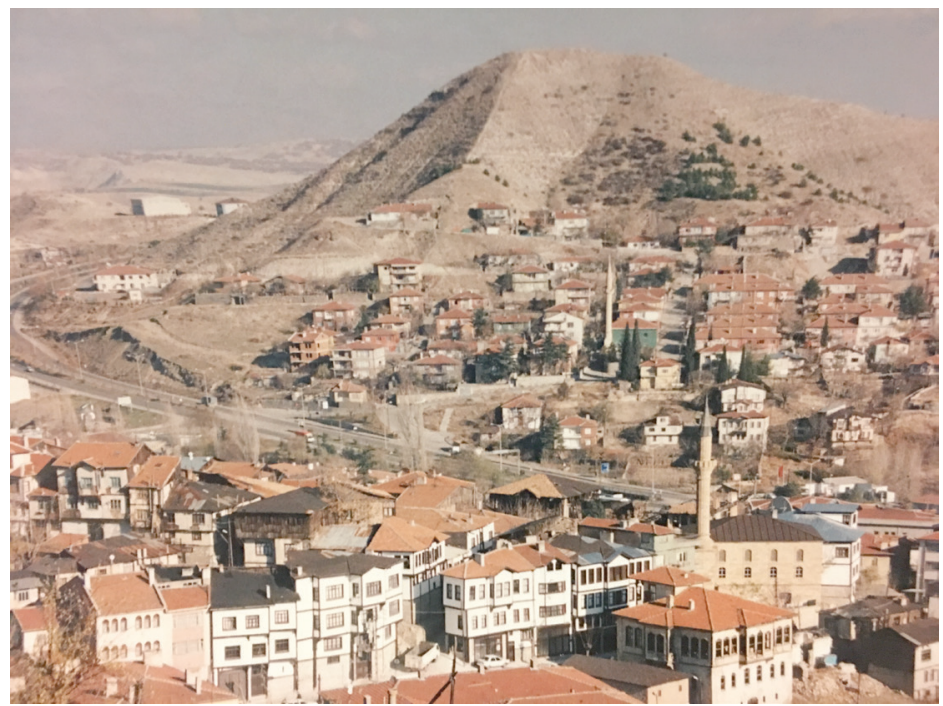

Fotoğraf 1: Ankara İstanbul karayolu

Kaynak: Yaşayan Müze Görsel Arşivi, 2001 
1960’l1 yıllarda ikiye bölünen kentte modernizmin tek değerli yaşam biçimini empoze eden ilkeleri öncelikle geleneksel yapılara yüklenen anlamların içini boşaltmıştır. Bu dönemdeki yapılar incelendiğinde gelenekselden kopuşun evin inşasında kullanılan yapı malzemelerinde, tekniğinde, mekân birimlerinin tek işlevli kılınmasında ve isimlendirilmesinde öne çıktığ1 görülür. Yerel olandan uzaklaşma, kullanılan bölgesel malzemelerin terk edilip abartılı bir ifade de olsa "tüm dünya" ile standart hâle gelmekle temellenir. Bu bağlamda ahşap, kerpiç, kara tuğla gibi geleneksel yapı malzemeleri terk edilmiştir.

Uğur Tanyeli, “Yeni Topluma Yeni Konut” başlıklı yazısında Cumhuriyet Türkiye'sinde geleneksel mekânlara karşı kapsamlı bir muhalefet yürütüldügünü belgeleriyle ortaya koyar. Örneğin bu dönemde ahşap konutun sağlıksızlığı savı uzun süre ciddiyetle savunulmuştur. Modern konut, artık çağdışı kaldığının altı çizilen geniş aile tipinin yerine geçmekte olan çekirdek ailenin yaşama mekânı olarak tanıtılmıştır (1998: 139-145). Beypazarı'nda ise, 1960’lı yıllarda konutun değişimini tetikleyen öncelikle teknolojik gelişmeler olmuştur. Suyun ve elektrik kullanımının ev içinde yaygınlaşması ve eski evlerde bu tesisatın bulunmayışı modern konuta karşı ilgi ve talep doğurmuştur. Aynı zamanda sanayileşmenin gelişmesiyle geleneksel konutta yer alan üretim alanlarına duyulan ihtiyacın ortadan kalkması modern olanı câzip hâle getirmiştir. 1980'li yıllarda ise, devletin modern olanı destekleyici tavrını o dönemde temini oldukça kolay hâle getirilen konut kredilerinde görmek mümkündür. Modern olana rağbet, cinsiyetlendirilerek de körüklenmiştir. Ev ne de olsa öncelikle kadının yaşama alanıdır. Isınma, temizlik, bakım kolaylığı ve bunların getirmiş olduğu rahat yaşam, kadın nüfus için ön plana çıkarılmıştır. Modern konut efsanesi sayılabilecek bu anlatmaların ve reklâmların geleneksel mekânın terk edilmesine veya yıkılıp yerine modern olanın inşasına ivme kazandırmış olduğu ileri sürülebilir.

Geleneksel Beypazarı evlerini oluşturan birimlerden bazıları modernleşme sürecinin başlangıcında dönüşüp değişirken, bazı birimlerin kullanımı da tamamen ortadan kalkmıştır. Örneklemek gerekirse, taşlık ya da hayat, metrekare olarak küçülmüş ayrıca işlev kaybına uğramış, üstelik yeniden adlandırılmıştır. Çok amaçlı olarak kullanılan ve geleneksel evin bağımsız birimleri olan odalara yeni adlar verilmiştir. Oturma, yatak, çalışma odası gibi adlarla yeniden biçimlenen odalar da bu minvalde işlev kaybına uğramıştır. Beypazarı evleri, Osmanlının son döneminde gelişimini tamamlayan ve adına "Türk evi” denilen yapılar içinde yer alır (Bektaş, 1996: 20, Arseven ve Küçükerman, 1995; Sakaoğlu 1988, Turgut-Ünügür 1992, Sözen 1992 ve Eruzun 1992). ${ }^{3}$ Bu sınıflandırma daha çok dönemseldir; çünkü, bu ortak dönemde inşa edilen bu yapılar, esas itibarıyla bir ana, ortak plana sahip olsalar da bölgesel, iklimsel ve ailesel ihtiyaçlar doğrultusunda birbirlerinden oldukça farklı karakterdedirler. Beypazarı evlerini Türk evi içinde farklı kılan yapılardan "messan" (mahzen) ve "kuşkana" modern mekânda yansıma bulamamıştır. Tepeliklere, mamraklara, sedir kuşaklarına da artık ihtiyaç kalmamıştır (Fotoğraf 2-3-4). Geleneksel evin dış cephe elemanlarından cumbalar, saçaklar; iç cephe elemanlarından sergenler, nişler, sedirler yine ötekileştirilip modern olandan uzak tutulmuştur. Evin yapı bileşenlerinden 1şıklıklı kapıların, muska tipi pencerelerin, kim geldi penceresinin üzerine kalın süngerler çekilmiştir (Fotoğraf 5-6). 


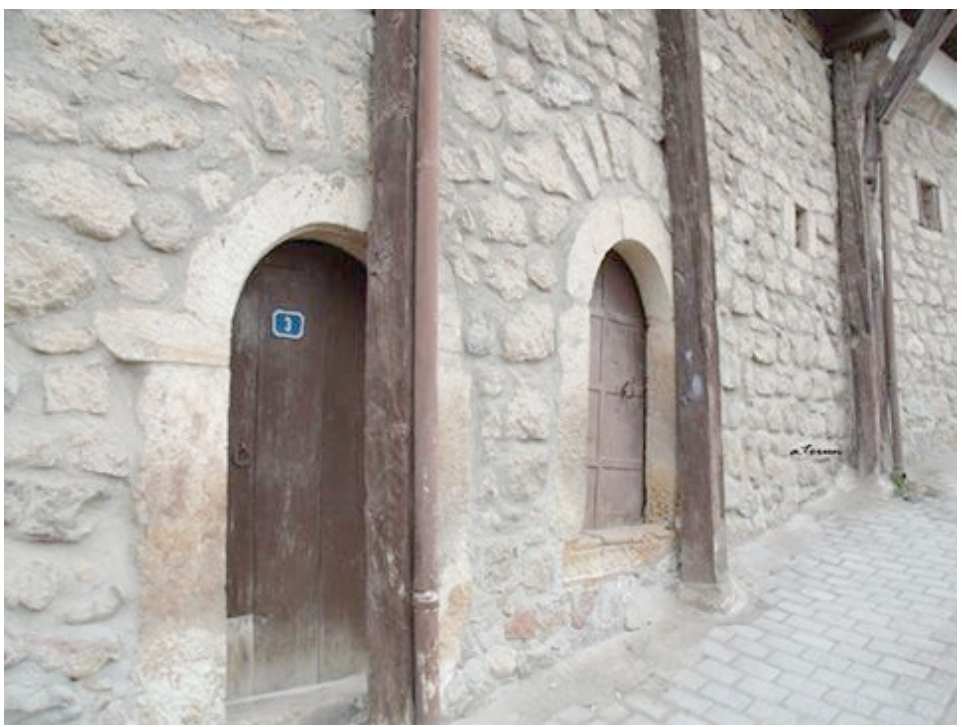

Fotoğraf 2: Mahzen

Kaynak: Ali Torun, Beypazarı Evleri

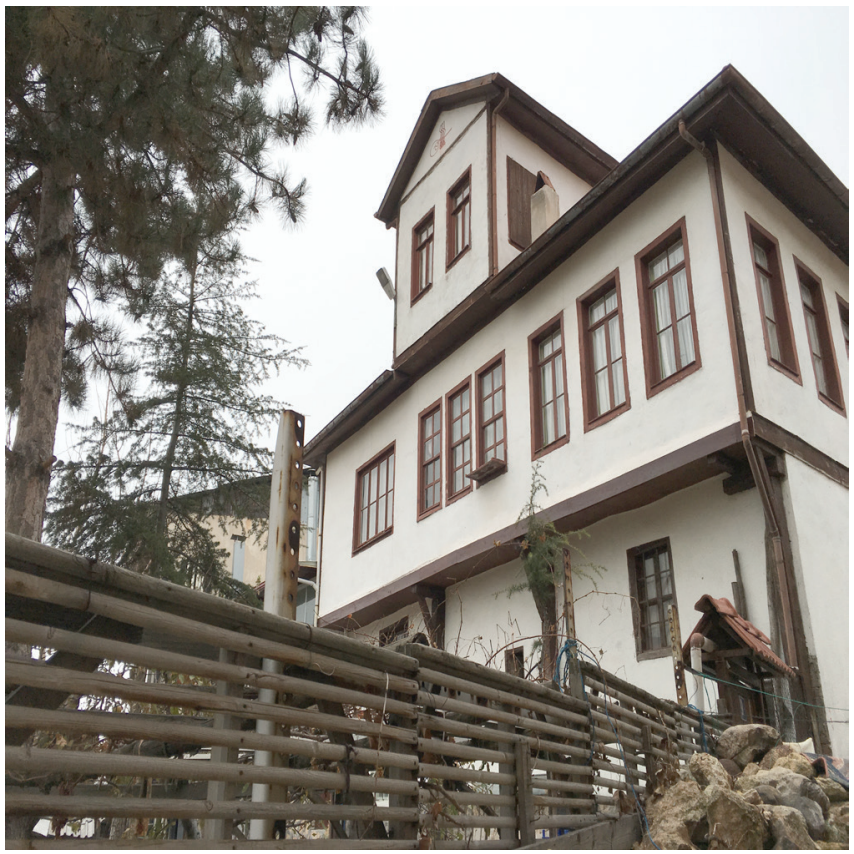

Fotoğraf 3: Kuşkanalı ev

Kaynak: Yaşayan Müze Görsel Arşivi, 2015. 


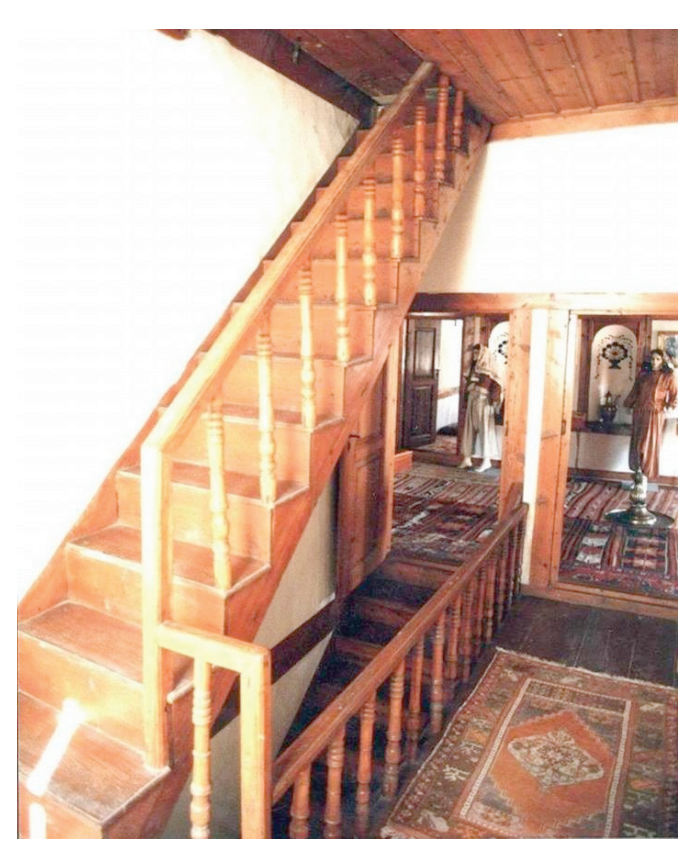

Fotoğraf 4: Mamrak

Kaynak: Beypazarı Belediyesi Görsel Arşivi

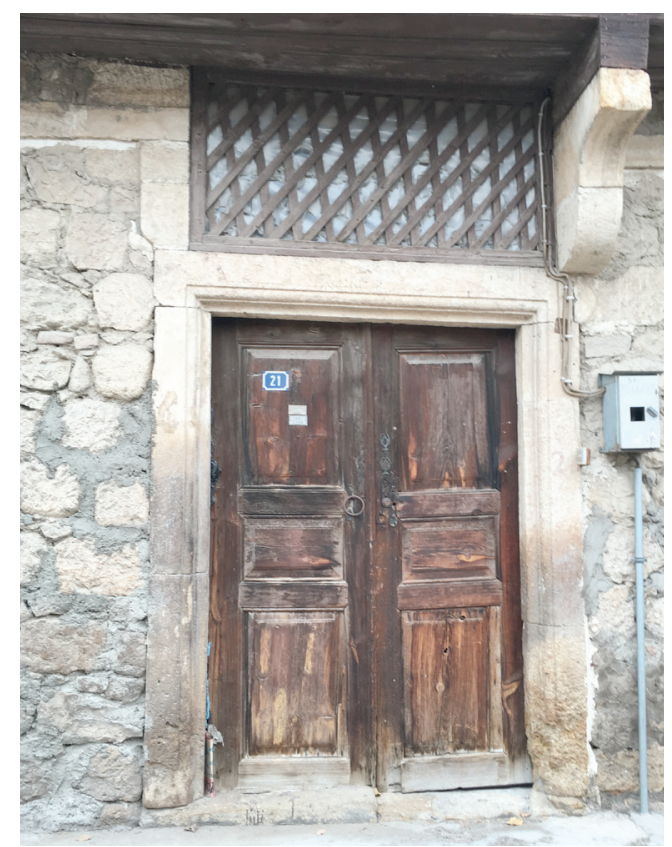

Fotoğraf 5: Işıklık

Kaynak: Yaşayan Müze Görsel Arşivi, 2016 


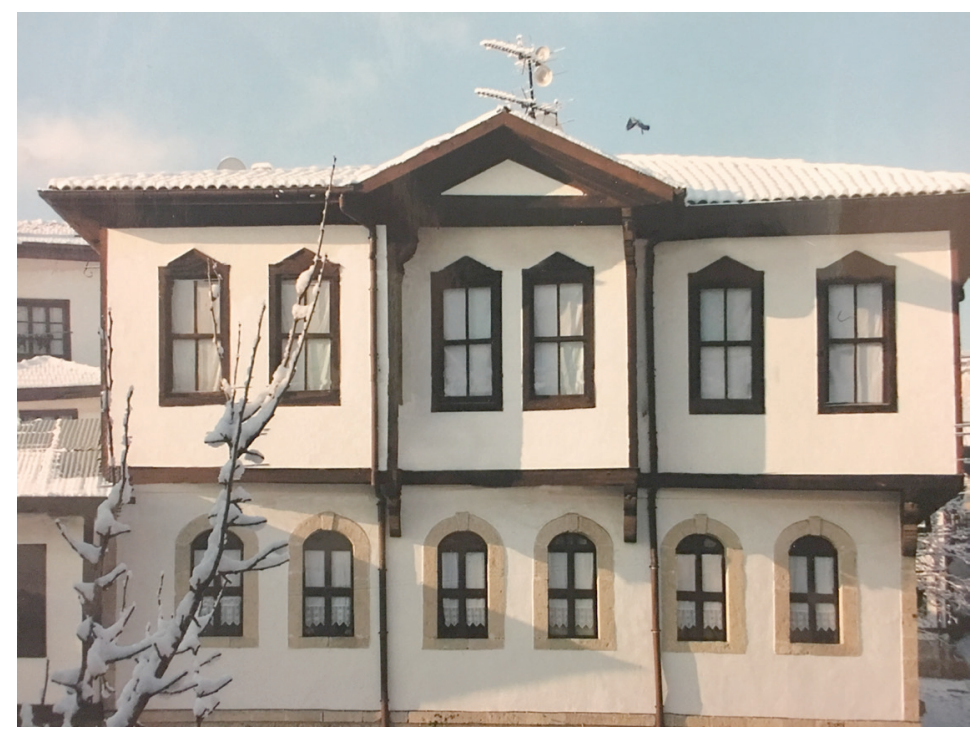

Fotoğraf 6: Muska tipi pencere

Kaynak: Yaşayan Müze Görsel Arşivi, 2016

Baudrillard'ın söylemiyle bu yapı unsurları bir anlamda öldürülmüştür (2005: 22). Geleneksel evi oluşturan bu mekân unsurlarına bağlı olarak kuşaktan kuşağa anlatılagelen mekân anlatıları da uzunca bir dönem için hafızalardan silinmiştir. Artık evin yapım aşamasında kullanılacak ağaçların ayın yenisinde ya da eskisinde kesilmesiyle ilgili olarak anlatılan efsanelerin, dile getirilen atasözlerinin ${ }^{4}$ bir değeri kalmamıştır. Özleme tekniği ile ilgili anlatılar tarih olmuş, mamrak ${ }^{5}$, cumba, kuşkana ${ }^{6}$ hikâyeleri son bulmuştur. Geleneksel yapıların bazılarında görülen çantı bölümüyle ilgili efsane, bunların içinde hem geleneksele hem de moderne göndermede bulunduğu için ilgi çekicidir. Eskiden Beypazarı'nda evin inşasında bir oda ya da tamamen bir kat daha sonraki bir dönemde tamamlanmak üzere sivanmadan bırakılırd1. Evin sıvanmadan bırakılan bu bölümüne "çantı" denir. Yörede geleneksel evin bu birimiyle ilgili olarak anlatılanlardan ilki mitik bir karaktere sahipken diğeri tamamen nesnel, modernist bir izâhtır. Efsaneye göre, bir insanın bu dünyada her şeyi tamam oldu mu, tabut kapıya dayanır. Çantı yâni sıvasız kalan bu yapı birimi ile ilgili başka bir anlatı daha doğrusu açıklama daha vardır. Bu açıklama ile çantının aslında tamamen ekonomik, maddî sebeplerle inşası yarım bırakılmış bir mekân olduğu anlaş1lır (Demir, 2003).

Bu çarpıcı örnek bir anlamda geleneksel ile modernin kendi kültürel ortamları içinde kendi kendilerine anlattıkları öykülerin içeriğinin, niteliğinin de hiçbir ortak noktada kesişmediğini gösterir. Modernizm geleneksel olanı keskin bir bıçak gibi kesip atmıştır. Bu çalışmada ele alınması mümkün olmayan miktardaki mekân anlatılarının çoğu da ötekileştirilerek, hurafe addedilmiştir. Yeni mekân anlatıları "üç oda bir salon" mitiyle dolayımlanır hâle gelip geleneksel evlerin antipropagandasını yapmanın ötesine geçememiştir. Gaston Bachelard, Mekânın Poetikası adlı özgün çalışmasında modernizmin mekânları nasıl birer meta hâline getirdiğini şu şekilde anlatır: 
Evin kökü yoktur. Buysa bir ev düşçüsü için akıl alacak şey değildir. Gökdelenlerin mahzeni yoktur. Kentteki yapıların yalnızca dış yüksekliği vardır. Asansörler merdivenin kahramanlıklarını yok eder. İnsanlar burada gökyüzüne oturmayı hak etmezler. Benim evim denen yer artık basit bir yataylıktan başka bir şey değildir (Bachelard, 1996:54).

\section{İmge derin gerçekliliğin yokluğunu gizler: Beypazarı evlerinin turizme açılması}

Modernizmle basit bir yataylık ya da dikeylik hâline gelen mekânlar, eğer mekân teknolojileri mekânı anlamlı hâle getirmeye yarıyorsa gelenekselin yeniden üretiminde bir kutuplaşma sağlayarak bu teknolojiler içinde yer alabilir. Modernizm bağlamında gelenekselin öteki olma süreci ve bu süreçte yaşanılanlara kısaca değindikten sonra öldürülen gelenekselin yeniden diriliş öyküsünü postmodernizm ve turizm bağlamında ele almak gerekecektir. Öncelikle postmodernizm ve modernizm tartışmaları ve postmodern kuramın toplumsalı algılayış biçimine bakmak faydalı olacaktır.

İmgenin basamaklarını sınıflandırdığı çalışmasında Baudrillard ilk basamakta imgenin derin bir gerçekliği yansıttığına değinir. İkinci aşamada ise imge, derin bir gerçekliği değiştirir ve gizler. Üçüncüsünde imge, derin bir gerçekliğin yokluğunu gizler. Son olarak imge, gerçekliğin hiçbir çeşidiyle ilişkisi olmayan kendi kendinin saf simülarkıdır. Bu sınıflamada belirtilen ilk ve ikinci aşama şimdiye kadar anlatılanları formülize etmektedir. Bu gerçeklik paradigmaları, üzerinde durulan konu bakımından gerçeği yansıtanın da gerçekliği gizlenenin ya da değiştirilenin de geleneksel mekân olduğunu ortaya koyar. Geleneksel yapıdan moderne ve kapalı ekonomiden kapitalist ekonomiye geçişte modernizmin ve kapitalizmin dinamikleri gelenekseli yeniden tarif etmiştir. Modernizmin bu baş döndürücü devingenliğinin sonuçları pek çok araştırmaya konu olmuştur. Modernizmin bir kırılma noktası olduğuna değinen Hakkı Yırtıcı, modernlikle geleneksel dünyanın kurum ve kurallarının çözüldüğünü, geleneksel olanın yabancılaştırıldığını anlatırken (Yırtıcı, 2005: 23) Anthony Giddens da Modernliğin Sonuçları adını taşıyan çalışmasında, bu kopuşu süreksizlik olarak tanımlar (2004: 14). Bu dönemde süreksizlikler sürekli akmış, gelenekten uzak olan daima kutsanmıştır. İçi boşaltılmış, edilgen, soyut, tek değerli-biçimli, çizgisel ve pasif bir duruma gelen modern mekân olarak apartman tersine çevirmeyle küreselleşen aynı zamanda çok kültürlüleşen günümüz postmodern yapıdaki üretim-tüketim ilkeleri doğrultusunda ve turizm bağlamında ötekileştirilen olmuştur. Postmodern kuramcıların çoğu ve özellikle Richard Baumann, modernizmin düzen rüyasını ve standart durumlar belirlemesini, göreceliği, belirsizliği ve muğlaklığı bastırma çabası olarak algılar. Bu çaba Bauman’a göre, ikili karşıtlıklar üretir. Bauman şöyle yazar:

Anormallik normalliğin ötekisi, sapma yasalara saygılı olmanın, hastalık sağlığın, barbarlık uygarlığın, hayvan insanın, yabancı yerlinin, düşman dostun, "onlar" "bizlerin", delilik aklın, yabancı devlet öznesinin, meslekten olmayan uzmanın ötekisi (Aktaran Smith, 2005: 315).

Bauman'ın ortaya koymaya çalıştığı şey toplumsal yaşamı bütünleştirme, tek tip ve değerlileştirmeye çalışan modernitenin sistematik ve mükemmelliyetçi yapısının sağlıklı olmadığıdır. Bu iki kuram, Newton ile Einstein'ın fiziği ele alışları kadar birbirine zıt görünmektedir. Görecelilik, postmodernizmin savunularını bir kelimeyle özetlemeye yetecektir. Philip Smith, 
postmodernistlerin bilimin ontolojik ve epistemolojik temellerine meydan okuduklarını, akıl ile duygu, nesnel bilgi ile kişisel deneyim arasındaki köklü ayrımları tartıştıklarını ve bilginin toplumsal yere göre üretildiğini iddia ettiklerini belirtir (2005: 316). Kapalı ekonomiden kapitalist ekonomiye ve günümüzde Smith'in belirttiği gibi imaj temelli ekonomiye geçiş ve mekânın postmodern zihniyette anlatıların önüne geçmesi geleneksel mekânların yeniden keşfine ve turizm alanında kullanımına zemin hazırlamıştır. Ancak elbette postmodernizmin, modernizmin temellendirdiği ve bir anlamda oluşturduğu bir gelenek üzerinden söz söylediği kabul edilmelidir. Baudrillard'ın imgeyle ilgili sınıflaması hatırlandığında bu durumu anlamak daha kolaylaşacaktır. İmgenin derin bir gerçeği yansıttığı modern öncesi geleneksel dönemi, imgenin derin gerçeği gizlediği, ötekileştirdiği, gerçeğin genlerini deformize ettiği hatta gerçeği öldürdüğü modern dönem takip eder. Bu dönemde aslında ortada gerçek adına bir şey bırakılmaz. Çünkü gerçek yok edilir, öldürülür. Gerçekliğin öldüğünü gösteren en önemli delil onu tekrar diriltmeye çalışma çabalarıdır. Bu ise Baudrillard'ın imge basamaklarından üçüncüsüyle anlatılmıştır: İmge derin gerçekliliğin yokluğunu gizler. Derin gerçeğini yâni kutsal söylemlerini, ritüellerini yitirdiğini anlayan ve tüketim girdabının içinde kaybolan toplumlar ellerinden uçup gidenin yokluğunu gizlemeye çalışırlar ve bu dönüşümü çeşitli üretim-tüketim ilişkileri içinde sürdürürler. Kültürün öldüğünü gizleme teknolojilerinin başında turizm gelmektedir. Çünkü turizm, modern insanın tüketme alışkanlıklarına ve öldürülenin diriltilmesine hizmet için gerekli olan illüzyonları üretmeye uygun bir mecradır. Turizm geleneği yeniden üreten bir teknoloji olarak pek çok imge içinden imgeleri seçer, dönüştürür veya olduğu gibi koruyacağını söyler. Bu yollarla simüle edilen ya da adına geleneksel denen şey, turizmin hammaddesi olur. ${ }^{7}$

Konuyu tekrar Beypazarı evleri üzerinden inşa edilen turizme getirdiğimizde kutsal olanın yeniden inşasına mekânlarla başlandığı görülür. Zira geleneksel mekânlar derin gerçekliğin imgesi hâline geldiği dönemde toplumu, bireyi biçimlendirmiş ve ortak kimliği inşanın aracı olmuştur. Yeniden üretim sürecinde bu eylemin tekrar edebileceği de düşünülmüştür. Bu bakımdan geleneksel mekânların kültür turizmi bağlamında yeniden üretilmesi demek, bu işleyişi tekrar çalıştırma denemesi demektir. Ancak unutulmaması gereken yeniden inşada kutsalın yeniden üretilmesinin koşulu ekonomiktir. Yeniden üretilen aslında geleneğin dirilişi, tekrar yaşanması değil bir meta hâline getirilmesidir. Gelenek, bir bakıma artık bir üründür. Kültür turizmi bağlayıcılığgnda gerçekleşen yeniden üretim yine bir dizi mekân teknolojisinin kullanımını gerektirir. Kültür turizmine açılan tüketim bölgesinde her şeyden önce imgeler Baudrillard'ın söylemiyle büyüleyici olmak zorundadır. George Ritzer de Büyüsü Bozulmuş Dünyayı Büyülemek adını taşıyan eserinde tüketim alanlarının insanları büyüleyici niteliğe sahip olması gerektiğini yazar (2000: 26). Ritzer'in, Schick'in mekânın yeniden üretim teknolojilerine özellikle turizm amaçlı yeniden üretim için büyülü hâle getirme teknolojisini eklediğini söyleyebiliriz. Büyüleyici olmak bir anlamda turist için bir çekim merkezi hâline gelmek demektir. Ritzer, büyüleyiciliği seyirlik olabilmekle, simüle edilmiş olmakla açıklar (2000: 144).

Beypazarı'nın 1994'ten itibaren Beypazarı Belediyesi tarafından yürütülen turizm çalışmaları çerçevesinde, Beypazarı evlerinin Beypazarı'ndaki imgeler arasından seçilip büyüleme aşamalarına tâbi tutulmasıyla yeniden üretim çarkının döndüğüne şahit olunur. Belirtilen bu yıllarda başlayan geleneksel yapıların restorasyon çalışmaları ile ilçedeki 3500 evin büyük bir kısmının dış cephe makyajları yapılmıştır (Fotoğraf 7-8). Sadece mekânlar değil 
geleneksel dönemde evin içinde akan gündelik yaşam da diriltilmek istenmiş ve bu yönde canlandırma senaryoları üretilmiştir. Dış cephe makyajı yapılan ve turizme uygun olan yapılar bu amaçla yeniden dekore edilmiş, geleneksel giyim kuşam, geleneksel mutfak canlandırılmıştır (Fotoğraf 9). Böylece, sürdürülen yeniden yapılanmada evler, sokaklar seyirlik hâle getirilir. Geleneksel yapıların yoğun olarak bulunduğu eski yerleşimde modern öncesi yaşamın sürdürüldüğü hissi verilmek istenmiş̧ir.
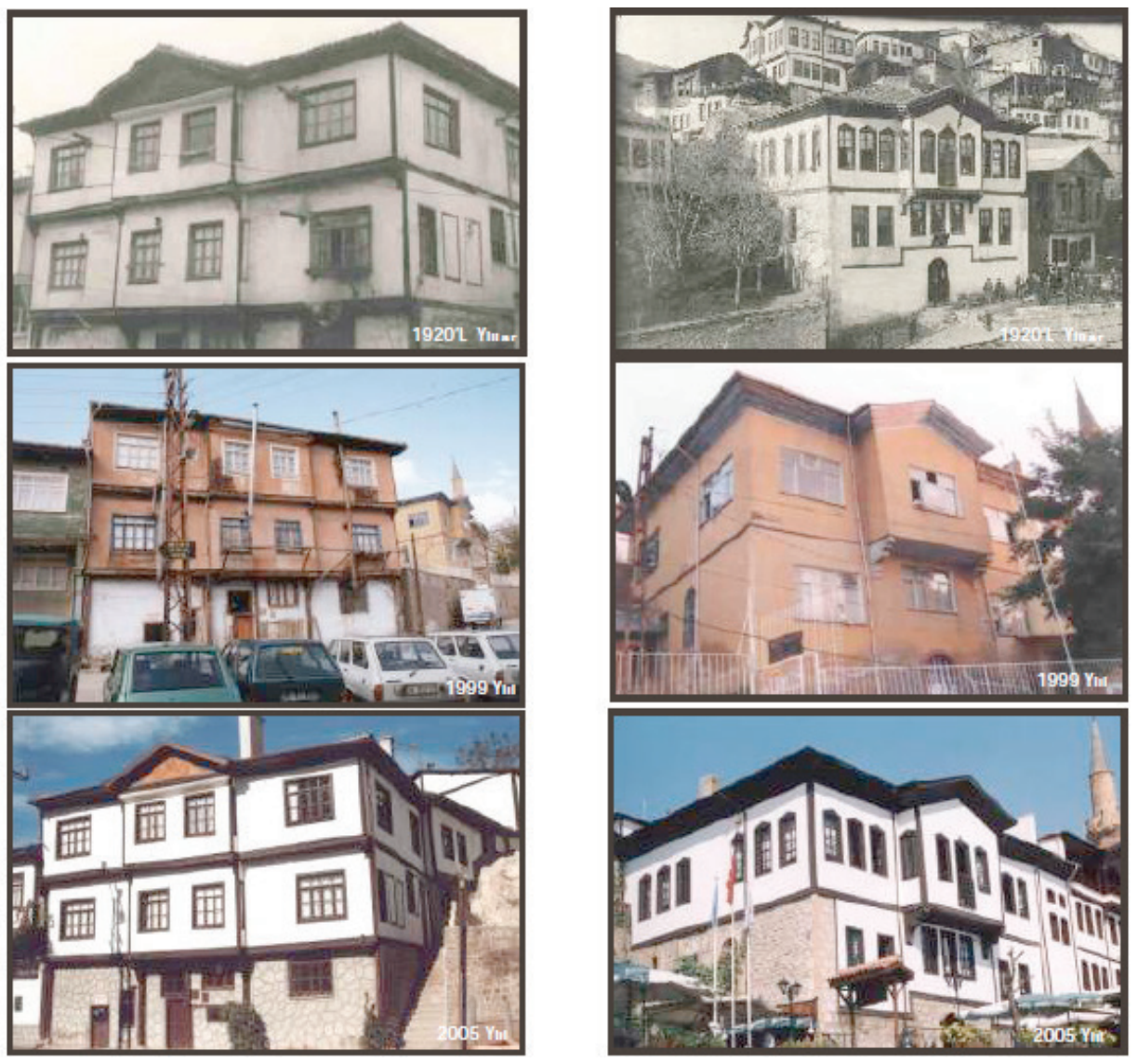

Fotoğraf 7: Cephe makyajı onarımı

Kaynak: Beypazarı Yeniden Proje Kitapçığı, 2005. 

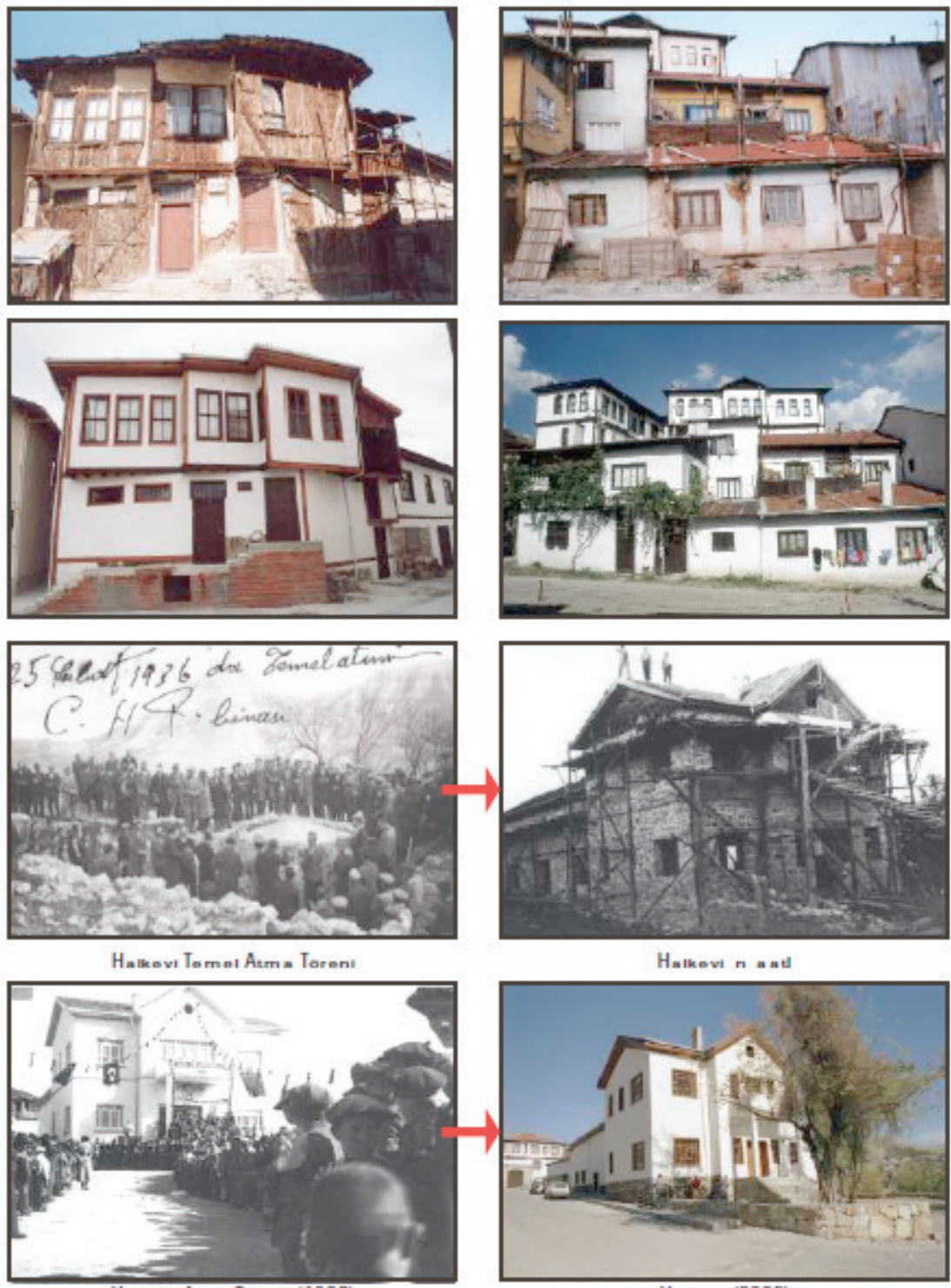

Halkavi Açili Tersm (1938)

Halkevi (2005)

Fotoğraf 8: Cephe makyajı onarımı

Kaynak: Beypazarı Yeniden Proje Kitapçı̆̆ı, 2005. 


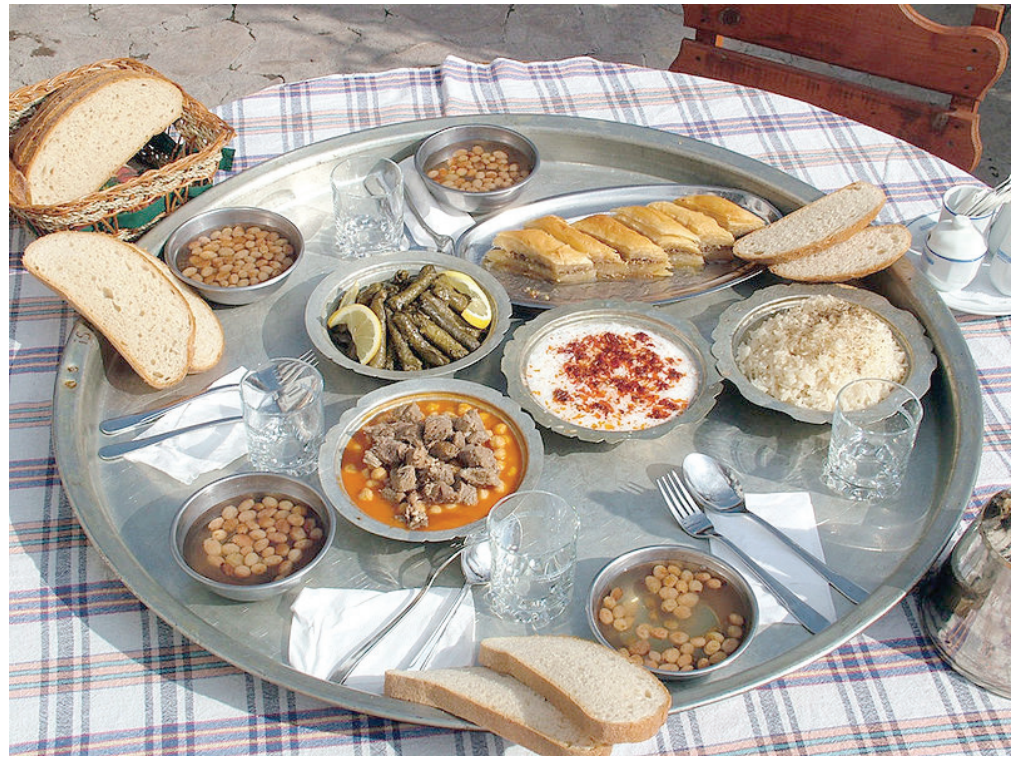

Fotoğraf 9: Yeniden canlandırllan Beypazarl mutfă̆

Kaynak: https://tr.wikipedia.org/wiki/Beypazart

MacCannell, Ermin Goffman'ın “sosyal hayatın ön ve arka bölgesi” tanımlamasından yola çıkarak geliştirdiği analiz biçimine göre, turistik bölgeler de, tıpkı sahne sanatlarında olduğu gibi, seyirciye sunulan ön kısımdan ve seyircinin hiç görmediği arka kısımdan oluşmaktadır. Turist çeken bölgeler sahne önüdür, turistler için hazırlanmıştır (MacCannell'den aktaran Kirshenblatt 1992: 300-303). Beypazarı'nda 1960'larda gelenekselin ötekileştirilmesinin sınırlarını çizen simge, İstanbul-Ankara kara yolu, bu kez turistler için hazırlanan sahne önünün ve gerisinin sınırını belirlemektedir. Ötekileştirilen modern yaşam alanları eğer sahne arkasındaysa zaten turist bakışının uzağında olduğu için bir sorun yaratmamaktadır. Ancak sahne önünde yer alan "öteki” turist için hazırlanan büyülü ortamın büyüsünü bozma tehlikesi taşır. Bir sahneye dönüştürülüp büyülü hâle getirilen eski yerleşim bölgesinde yeniden üretimi gereken geleneksel evlere makyaj yapılırken büyülü atmosferi bozacağı düşünülen ve dolayısıyla öteki olan modern binalara ise, kamuflaj uygulanmaktadır. Kamuflaj uygulaması kısaca “öteki” olanın kimliğinin gizlenmesi ve "biz” denmiş gibi görünmesini sağlama çabası olarak tanımlanabilir. Bu uygulama Beypazarı'nda eski yerleşim sınırları içinde 1960'lardan sonra yapımı gerçekleşen çarşı binalarına ve trafolara da uygulanmıştır. Tamamen modern zamanın ürünü olan bu yapılar "bindirme" denen bir teknikle otantikleşmiş olurlar ya da otantik gibi görünürler (Fotoğraf 10-11). Bu uygulamalara ek olarak geleneksel dokuya uygun görülmeyen bazı sokak mobilyaları, vitrinler, büfeler de kamuflaj yöntemiyle saklanmıştır (Fotoğraf: 12). 

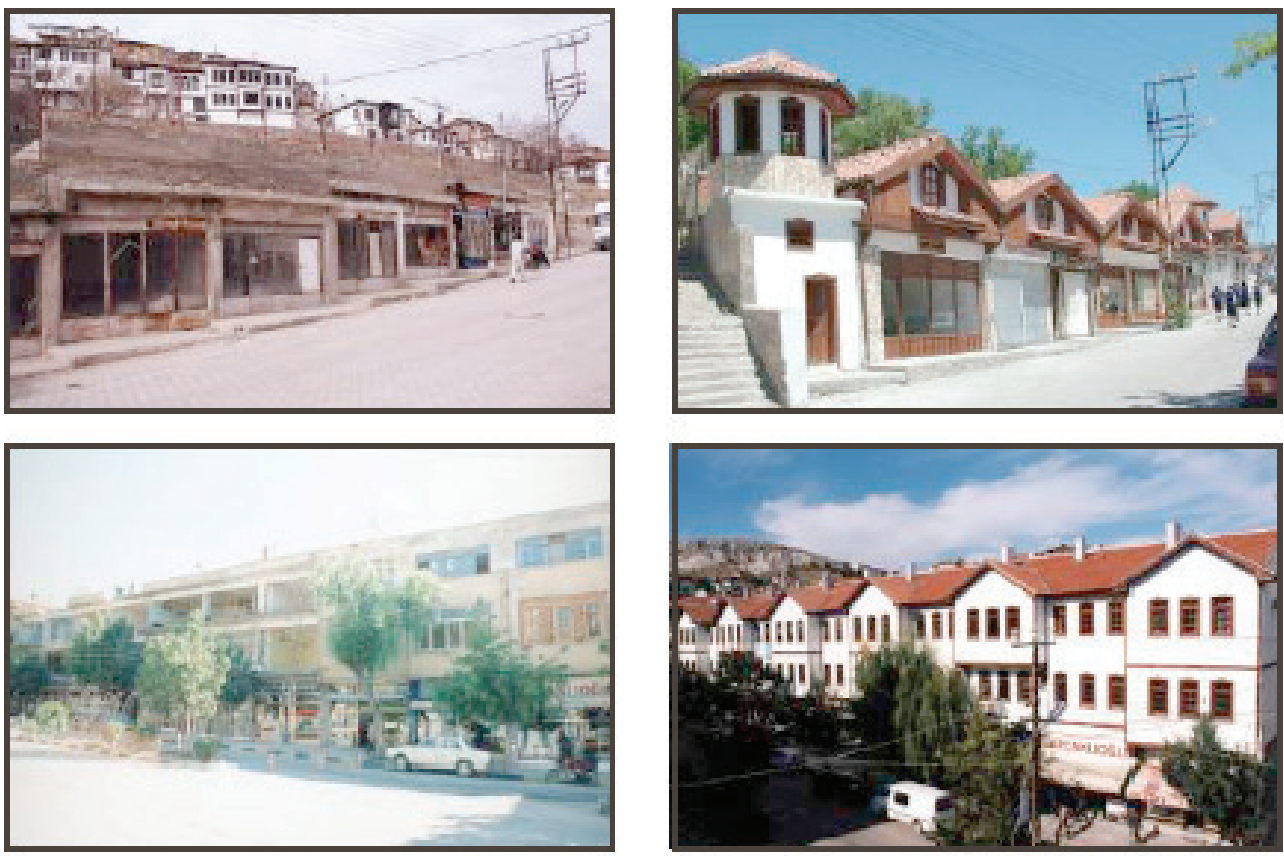

Fotoğraf 10: Bindirme tekniği ile betonarme yapıların kamuflajı

Kaynak: Beypazarı Yeniden Proje Kitapçı̆̆ı, 2005.
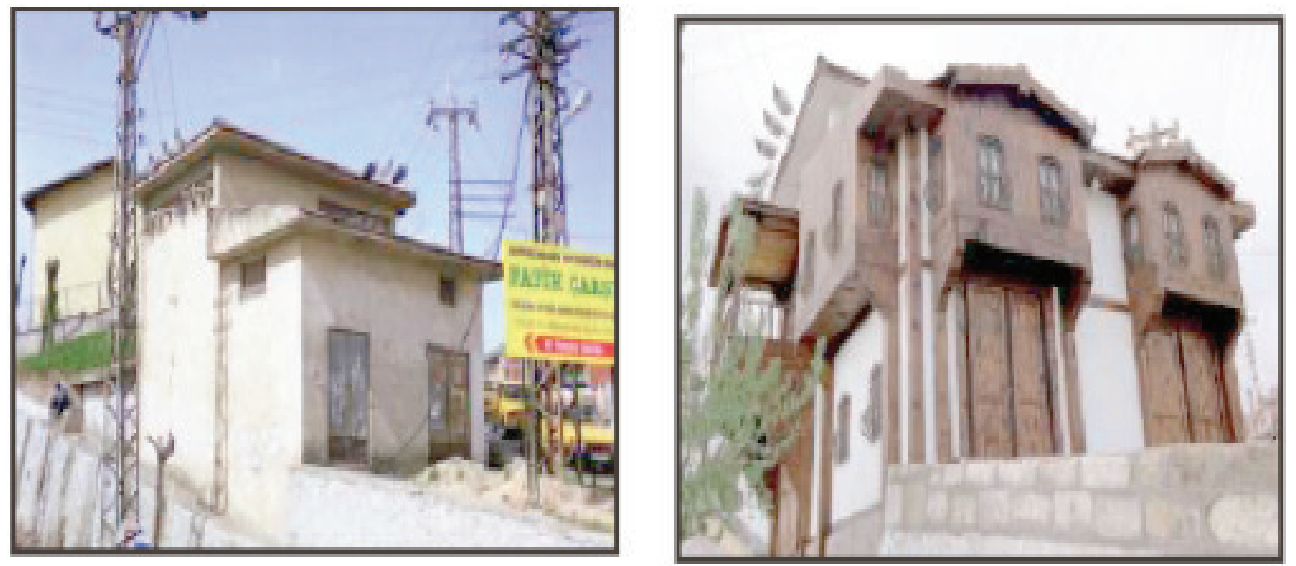

Fotoğraf 11: Betonarme yapıların kamuflajı

Kaynak: Beypazarı Yeniden Proje Kitapçığı, 2005 

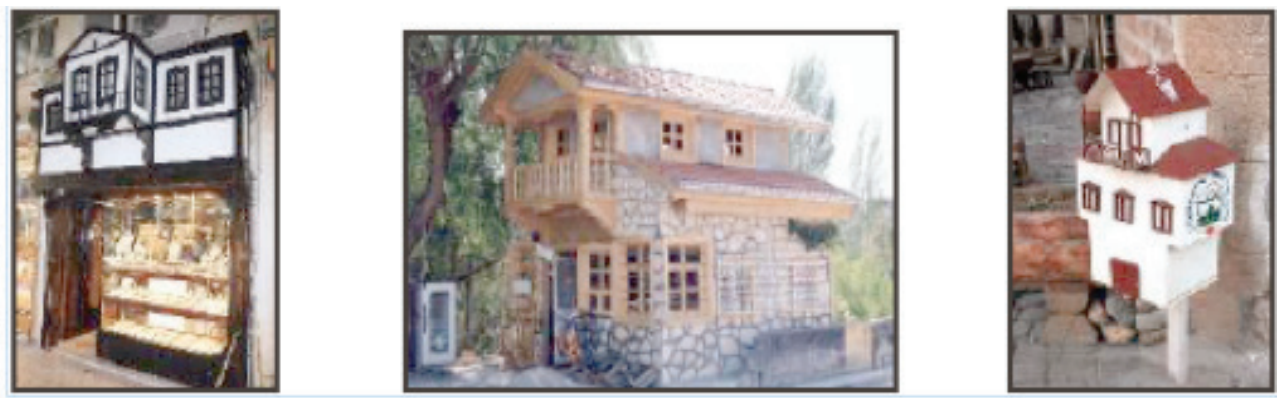

Fotoğraf 12: Kamuflaj yöntemiyle saklanan modern unsurlar

Kaynak: Beypazarı Yeniden Proje Kitapçı̆̆ı, 2005

\section{Sonuç}

Modernizm ve postmodernizm bağlamında ve turizm ekseninde değerlendirilen geleneksel mekânların dönüştürülmesinin ele alındığı bu çalışmada sonuç olarak ifade edilecekler modern olanın ötekileştirildiği süreçle yani postmodern durumla sınırlı kalacaktır. Geleneksel mimarî, folklorun bir parçası olarak kendiliğindenliğin, kolektif belleğin sonucudur. Turizm açısından geleneksel yapıların postmodern istekler doğrultusunda yeniden canlandırılması sahne önündeki gelenekselin yeniden üretilmesi önceden belirlenen bir hedefe ulaşmak üzere planlı eylemler bütününü anlatmaktadır. Sahne önünde yer alan geleneksel yapıların yenilenmesini "makyaj", modern olanın ötekileştirilmesini ise "kamuflaj” sözcükleriyle okuduğumuz bu postmodern durum, folklorun gerçek dünyasından uzak görünmektedir. Kültürün yeniden üretimiyle kültürün korunması ve yaşatılmasının sağlandığı yolundaki söylemlerin doğruluğu ya da yanlışlığı fikrinden sarf-ı nazar ederek kültür turizminin araçlarıyla büyülü mekânlar yaratmada amaçlananın asıl olarak geleneğin korunması ve sürdürülmesi olduğu söylenemez.

Kültür turizmi, mekânları dönüştürür, mekânın içinde geçen "geçmiş gelenek” ya da "ara zamanlı ve/veya sabitleşmiş folklor ürünü (mütekâmilleşmiş - ölü)"§ olarak adlandırabileceğimiz folklor kesitini diriltir. Bu dönüşüm için anonim söylemi tekrar kullanır. Burada değişen bağlamdır. Bağlam, folklorun yaşayan ya da sabitleşmiş değerleri için birbirinden farklı anlamları çağrıştırır. Yaşayan folklor ürünü için bağlam doğal ve kendiliğinden oluşan bir ortamdır. Sabitleşmiş bir malzeme içinse kurgulanmışlık ve yapaylık bağlamın karakteri haline gelir (Demir, 2017:47). Turizm için kullanılan "sahne” metaforu, özellikle kültür turizminin kurgusal doğasını en iyi şekilde anlatır. Turizm destinasyonu hâline gelebilmek, bir anlamda sahne diyebilmek için sahne makyajı da gizleme, maskeleme anlamında kamuflajı da şarttır.

Kültür turizminde amaç bireylerde yâni turistlerde bir bilgi eksikliği hissi yaratıp bunun tatmin edilmesini sağlamaktır. Böylece çekim merkezi hâline getirilen bölge ya da şey üzerinden ekonomik kârlılık amaçlanır. Bu bağlamda her biri "ara zamanlı ya da sabitleşmiş folklor ürünü” hâline gelen geleneksel yapıların ve çevresinde teşekkül eden kültürel bilginin yeniden üretimi ile adını duyuran Beypazarı, turistlerin talebini kazanarak turist rehberlerinde kendine nadide bir yer edinmiş ve turizm endüstrisinden kendine düşen payı almaya hak kazanmıştır. Beypazarı kültür turizminin inşa sürecinin postmodern kuramlar üzerinden değerlendirildiği bu çalışma, kurama yeni açılımlar kazandırmak için elbette yeterli değildir. Beypazarı gibi kültür turizm destinasyonlarına dünyadan ve Türkiye'den verilecek örnekler, bunların postmodern kuramlar açısından tetkiki ile kurama katkı sağlamak mümkün olacaktır. 


\section{Notlar}

1 Konuyla ilgili bakınız: L., Bernard. Modern Türkiye’nin Doğuşu, Arkadaş: Ankara, 2009. ss. 57-103.

2 Bu makalenin üretilmesinde Beypazarı Evleri-Sosyo-Kültürel Değişim Bağlamında Bir Bakış başlıklı tez çalışması kapsamında gerçekleştirilen alan araştırmaları ve sözlü tarih kayıtlarından yararlanılmıştır.

3 Anadolu coğrafyasında görülen geleneksel yapılara verilen isim konusunda mimarlar, sanat tarihçiler ve halk bilimcilerin bir uzlaşı içinde oldukları görülür. "Türk evi” pek çok etkenin etkisi altında oluşmuşsa da asıl karakterini Osmanlı Devletinin egemenliği altındaki Rumeli ve Anadolu'nun belirli bir coğrafî alanında bulmuş ve özellikleri belirginleşmiştir (Bektaş 1996: 20; Akıncı 2000: 12; Kuban 1975:75; Eldem 1993:17'den aktaran Demir, 2003). Geleneksel Türk evleriyle ilgili araştırmalarda ev için farklı adlar kullanılmıştır. Örneğin sözü edilen evleri, Arseven ve Küçükerman (1995), Bektaş (1996, 2001), Sakaoğlu (1988), Turgut-Ünügür (1992), Sözen (1992) ve Eruzun (1992) “Türk Evi”; Akdemir (1994) ve Keskin (1994) “Anadolu Evi”; Kuban (1995), Başkan (1986)"Anadolu Türk Konutu”; Eldem ve Ulusu “Osmanlı- Türk Konutu-Evi”; Karpuz ve Aksoy, "İslâm Türk Konutu”; Akıncı (2000) ise, "Geleneksel Türk Sivil Mimarîsi” olarak adlandırmışlardır. Verilen bu isimler bahsedilen ev üzerinde daha etkili olan ya da ortak etkisi bulunduğuna inanılan kültürlerin varlığından yola çıkılarak konulmuştur. Birbirinden farklı isimlerle adlandırmalarına rağmen, mezkur araştırmacılar, XVIII. yüzyılda Osmanlı Devleti sınırları içinde şekillenen evleri, geleneksel Türk evi olarak adlandırmaktadırlar. Söz konusu bu evler için “Türk evi” adlandırmasının Benedict Anderson'ın düşüncelerinin perspektifinde yorumlayarak hayalî, icat edilmiş olduğunu (Bertram, 2012: 39) ileri süren bilim insanları da bulunmaktadır. Konuyla ilgili kaynakçada künyesi verilen Carel Bertram'ın Türk Evini Hayal Etmek Eve Dair Kolektif Düşler adlı çalışmasına bakılabilir.

4 Geleneksel evin yapımı için kullanılacak olan ağaç, ayın yenisinde kesilirse o ağaçtan yapılan evler dayanıklı, uzun ömürlü olmaz. Ağaç, ayın eskisinde yâni dolunayda kesildiğinde uzun ömürlü olduğuna dair anlatılan “mekân anlatısı” yapı ustalarının belleğinde kalanlardandır .”(Tiftik, Sabri. 1949 Beypazarı doğumlu ve marangoz ustası olan kaynak kişi ile 04.01.2003- 24.02. 2003- 12.03.2003-20.05.2003 tarihlerinde yapılan görüşmelerin ses ve görüntü kayıtları Z. Sema Demir arşivindedir.) Sözlü kültürde bu inancı içeren atasözlerine birkaç örnek verilebilir: "Ayın yenisinde yapılan işten hayır gelmez”, "Dolunay’ı bekle, bereketini gör" "Ayın yenisinde olur börtü böcek, eskisinde olur börek çörek", "Kesme odunu ay büyürken, kırk koyunu küçülürken" (Baydar, 2012).

5 Beypazarı evlerinde alt kattan üst kata çıkışta merdiven başlarında adına "mamrak" denen kapaklar bulunmaktadır. Mamrak, geçmişten günümüze farklı işlevlerde kullanılmıştır. Cumhuriyet'in ilanından önceki dönemde, savaş sırasında sıkça yaşanan çete çatışmalarında herhangi bir baskına karşı kullanıldığı belirtilirken, Cumhuriyet'in ilanından sonra, bu kapakların, özellikle geceleri çocuklar uyur-uyanıkken düşmelerini engellemek veya alt kattan soğuğun girmesini önlemek için kullanıldıkları ifade edilmektedir. Bunun yanı sıra, mamrağın alt kattaki mutfaktan çıkan merdivenin üst kattaki odaya açılmasını sağlayarak yemek servisini kolaylaştırma işlevini de yerine getirdiği söylenmektedir. Bu kapaklar, 1960’lı yıllardan sonra kiracı ailelerin yaşadığ bu evlerde, evi paylaşanların birbirlerini rahatsız etmemek için kullanılan bir bölüm haline gelmiştir. Aynı evi paylaşan bu insanlar, zaman içinde akraba gibi olduklarından, mamrakların kapatılmasının ayıp karşılanmasıyla ilgili anlatılar da mevcuttur.

6 Kuşkana, tavan arasının, çatıdan yükselerek çıkan bölümüdür. Evin bu bölümüyle ilgili olarak mekân anlatıları mevcuttur.

7 Yöredeki yeniden canlandırma örnekleri pek çok folklor ürünü üzerinden gerçekleştirilmektedir. Konuyla ilgili Kara, Çiğdem. Turistik Ticarî Halkbilimsel Ürünler ve Beypazarı, Millî Folklor, 2011, Y. 23, S. 89, ss. 54-65'e başvurulabilir.

8 Sabitleşmiş" mefhumunu zihinlerde biraz daha netleştirmek için folklor ürününün iktidarını kaybetmiş olanı için kullandığımızı ifade etmeliyiz. Toplumun büyük bir kısmı tarafından unutulanlar sandığında ve müzede yerini almış folklor ürünlerini UNESCO 1989 Geleneksel ve Popüler Kültürün Korunması Tavsiye Kararı Metninde "sabitleşmiş folklor ürünleri” olarak adlandırmaktadır (Aktaran Oğuz, 2009: 147-152). Folklor, geçmişten günümüze gelenekle ve bellekle ilişkisi bağlamında "sabitlenmiş folklor ürünleri”, "ara zamanlı folklor ürünleri” ve “yaşayan folklor ürünleri”ni kapsayıcıdır. Ara zamanlı folklor ürünü ise kültürel bellek kuramları ve gelenek tanımları minvalinde bilgi nesnesine dönüşüm sürecinde olanları tanımlamaktadır. Yaşayan folklor ürünü ile gelenek bu tasnifte eş anlamlı olarak yer almıştır (Demir, 2017:47-52).

9 Konuyla ilgili bakınız: Lewis, Bernard. Modern Türkiye’nin Doğuşu, Arkadaş: Ankara, 2009. s. 57-103. 


\section{Kaynaklar}

[Ankara İstanbul karayolu fotoğrafi] Kaynak (2001) Yaşayan müze görsel arşivi.

Bachelard, G. (1996). Mekânın poetikası. İstanbul: Kesit.

Baudrillard, J. (2005). Simülarklar ve simülasyon. (O. Adanır, Çev.). Ankara: DoğuBatı.

Bektaş, C. (1996). Türk evi. İstanbul: Yapı Kredi

Bertram, C.(2012). Türk evini hayal etmek eve dair kolektif düşler. İstanbul: İletişim.

[Betonarme yapıların kamuflajı] Kaynak (2005) Beypazarı Yeniden Proje Kitapçığı.

Beypazarı Yeniden Proje Kitapçı̆̆

[Bindirme tekniği ile betonarme yapıların kamuflajı] Kaynak (2005) Beypazarı Yeniden Proje Kitapçığı.

[Cephe makyajı onarımı ] Kaynak (2005) Beypazarı Yeniden Proje Kitapçığı.

Demir, Z.S. (2003). Beypazarı evleri-sosyo-kültürel değişim bağlamında bir bakış (Yayımlanmamış Yüksek Lisans Tezi). Hacettepe Üni. SBE, Ankara.

Demir, S. (2017) Sözel belleğin müzede sergilenişi. İstanbul: Fanus.

[Işıklık ] Kaynak (2016). Yaşayan Müze Görsel Arşivi.

[Kamuflaj yöntemiyle saklanan modern unsurlar] Kaynak (2005) Beypazarı Yeniden Proje Kitapçı̆̆1.

Kara, Ç. (2011). Turistik ticarî halkbilimsel ürünler ve Beypazarı. Millî Folklor, Y.23, S. 89, ss. 54-65.

Kirshenblatt, B.G. and Edward M. B. (1992). Tourism foklore, culttural performances, and popular entertaintmets, a communications-centered handbook. (R. Bauman, Ed.). New York: Oxford Universty.

Lewis, B. (2009). Modern Türkiye’nin doğuşu. Ankara: Arkadaş.

[Mahzen] Kaynak: Ali Torun, (2014) Beypazarl evleri.

[Mamrak] Kaynak (2015) Beypazarı belediyesi görsel arşivi.

[Muska tipi pencere] Kaynak (2016) Yaşayan müze görsel arşivi.

Oğuz, Ö. (2009). Somut olmayan kültürel miras nedir? Ankara: Geleneksel.

Ritzer, G. (2000). Büyüsü bozulmuş dünyayı büyülemek. (Ş.S. Kaya, Çev.). İstanbul: Ayrıntı.

Schick, İ.C. (2000). Batının cinsel kıyısı. İstanbul: Tarih Vakfı Yurt.

Smith, P. (2005). Kültürel kuram. İstanbul: Babil.

Tanyeli, U. (1998). Yeni topluma yeni konut üç kuşak cumhuriyet. İstanbul: Türkiye Tarih Vakfi.

Tiftik, S. 1949 Beypazarı doğumlu ve marangoz ustası olan kaynak kişi ile 04.01.2003- 24.02. 200312.03.2003-20.05.2003 tarihlerinde yapılan görüşmelerin ses ve görüntü kayıtları Sema Demir arşivindedir.

Torun, A. (2014) Beypazarı evleri. Kendi yayını.

Yırtıc1, H. (2005) Çağdaş kapitalizmin mekânsal örgütlenmesi. İstanbul: İstanbul Bilgi Üniversitesi.

\section{Elektronik kaynaklar}

Baydar, Hüseyin. (2012) Ayın evreleri ve tarımsal faaliyetler, Şereflikoçhisar Çengel Siyasi Gazete.

16 Şubat. (Erişim: 05.03.2017). http://www.sereflikochisarcengel.net/ yazar.asp?yaziID=3524\&

Baslik=ayin-evreleri-ve-tarimsal-faaliyetler-profdrhasan- .

[Yeniden canlandırılan Beypazarı mutfağı fotoğrafi] https://tr.wikipedia.org/wiki/Beypazar1 